\title{
真空放電の制御と応用
}

$\begin{array}{llllll}\text { 正員 山本 修* } & \text { 正 員 齊藤 } & \text { 芳男 } * * \\ \text { 正 員 大久保 仁*** } & \text { 正 員 堀田 } & \text { 栄喜 } * * * * \\ \text { 正 員 山内 邦仁 } * * * * & \text { 正 員 鶴田 } & \text { 浩一 } * 5\end{array}$

\section{Control and Application of Discharges in Vacuum}

Osamu Yamamoto*, Member, Yoshio Saito**, Member, Hitoshi Okubo***, Member, Eiki Hotta****, Member, Kunihito Yamauchi****, Member, Kouichi Tsuruta*5, Member

Vacuums have been attractive media for researchers and industry to obtain useful plasma, energized particles and current switching effects. These applications require sophisticated control of high voltages or high electric fields, plasma parameters such as density and temperature of charged particles, potential distribution, etc. This article reports current topics on the electrical insulation and plasma application in vacuum.

キーワード : 真空中の絶縁, プラズマ応用, 二次電子放出, 高電圧真空遮断器, 中性子源, 陽子源, パルスX線源

Keywords : Insulation, plasma application, SEY, high voltage vacuum interrupter, neutron and proton sources, pulse X-ray source

\section{1. はじめに}

真空中の放電に関する研究を概観すると様々な切り口が 見えてくるが，一言で表すならば放電を如何に制御するか, となるであろう。制御対象の一つは真空中での高電圧ない し高電界, すなわち電気絶縁であり, 真空遮断器, パルス パワー機器を含む各種の荷電粒子加速器・発生器, 人工衛 星搭載の太陽電池パネル, 電子源を用いる次世代薄型ディ スプレイなど電力, 高粒子エネルギー, 真空マイクロエレ クトロニクスその他の幅広い真空を応用する機器の開発と 関連している。もう一つの対象は真空中でのプラズマであ り, 密度や温度, イオンの価数, 電位分布さらには污損物

\footnotetext{
* 京都大学大学院工学研究科

厂615-8510 京都市西京区京都大学桂

Kyoto University

Kyotodaigaku-katsura, Kyoto 615-8510

** 高エネルギー加速器研究機構

干305-0801 つくば市大穂 1-1

KEK-High Energy Accelerator Research Organization

1-1, Oho, Tsukuba 305-0801

*** 名古屋大学エコトピア科学研究所

干464-8603 名古屋市千種区不老町

EcoTopia Science Institute, Nagoya University

Furo-cho, Chikusa-ku, Nagoya, 464-8603

*****東京工業大学大学院総合理工学研究科

T226-8502 横浜市緑区長津田町 4259

Tokyo Institute of Technology

4259 Nagatsuta, Midori-ku, Yokohama 226-8502

*5 茨城大学工学部

干316-8511 日立市中成沢町 4-12-1

Ibaraki University

4-12-1, Nakanarusawa-cho, Hitachi 316-8511
}

質（金属ドロップレット）の除去なども含まれ，その新し い応用には表面改質やナノ物質の生成, 中性子発生源やパ ルス X 線源の開発などがある。

電気学会放電技術委員会では過去に 3 回の真空中の放電 に関する調査専門委員会が組織され, 上述した制御と応用 に関する調査報告書 ${ }^{(1) \sim(3)}$ が刊行されている。また, 現在は 放電を有効に制御するために電極や固体絶縁材料の表面物 性, プラズマパラメータなどを含む基礎特性の計測とシミ ユレーション技術の調査をおこなう「真空中における放電 制御のための高度計測・シミュレーション技術」調查専門 委員会が活動しており, 本特集号はその一環として企画さ れたものである。この解説記事では絶縁の観点から (1) 真 空中の沿面絶縁に重要な固体絶縁体材料の二次電子放出と 帯電現象の基礎, (2) 環境負荷が小さい電力用遮断器とし て注目されている高電圧真空遮断器の開発における技術的 課題をとりあげた。また, 真空中プラズマの応用の観点か ら (3) 地雷探查や医療診断への適用が考えられている簡 易型中性子／陽子源開発の技術課題, および (4) 各種の分 析・診断を可能とする可搬型パルス軟X線源の開発をとり あげ，それぞれについて専門の立場から紹介する。

\section{2. 絶縁体材料の二次電子放出と沿面放電}

真空中に置かれた絶縁体材料の主として沿面での絶縁破 壊（フラッシオーバ）の電界強度は, 経験的にはおよそ 1 $\mathrm{kV} / \mathrm{mm}$ 程度と言われており, 実際に, 機器設計に際しては これを目安とすることが多い。しかしながら, 近年, 機器 
のダウンサイジングや高電圧化が要求され，さらに高い電 界強度に対して安定な絶縁特性を持つ材料や表面処理の開 発が望まれている。絶縁体, 真空, 金属電極の界面である トリプルジャンクションに外部電界が印加された場合につ いては，そこからの電子の電界放出，絶縁体表面への電子 の入射，および二次電子放出および帯電という放電前駆機 構が古くから指摘されている。実際には，外部電界が無い 場合でも，X 線や電子，イオンの照射による二次電子放出 と帯電が放電あるいは材料の劣化などの誘因となることも ある。二次電子放出と帯電の 2 つの現象は, このように絶 縁材料表面での放電の前駆過程を支配するものであり, 詳 しく研究を進める必要がある。

$\langle 2 \cdot 1\rangle$ 二次電子放出 絶縁材料からの二次電子放出 係数は金属材料での值（1 から 2 程度）に比べ数倍大きい。 一般に二次電子放出特性は, 以下のように, 入射一次粒子 のエネルギー散逸過程と, 生成された二次電子の材料内で の散乱過程との 2 つの非弾性散乱現象の総和と考えること ができる。

入射粒子のバルク内でのエネルギー損失とそれによる二 次電子の生成個数 $n$ との関係は, 入射エネルギーを $E$, 二次 電子生成に必要なエネルギーを $\beta$ とすれば，深さ方向の座 標を $z$ として,

$$
n(z)=-\frac{1}{\beta} \frac{d E(z)}{d z}
$$

で表される。一次粒子のエネルギー散逸過程を示す右辺 $d E / d z$ として，例えば，Betheの式などが想定される。

$$
-\frac{d E(z)}{d s}=\left(\frac{N_{A} e^{4}}{8 \pi \varepsilon_{0}^{2}}\right)\left(\frac{Z \rho}{A}\right) \frac{1}{E} \ln \frac{2 E}{J}
$$

ここで， $s$ は一次粒子の飛程（線形飛程）であり，侵入深 さ（投影飛程）に換算して(1)式と結びつける必要がある。 なお, $N_{A}$ はアボガドロ数, $e$ は素電荷, $\varepsilon_{0}$ は真空の誘電率, $Z$ は原子番号, $A$ は原子量, $\rho$ は密度, $J$ は平均のイオン化 エネルギーである。(2)式は，エネルギーが高い場合は，お よそ $1 / E^{\alpha}$ で減少していく関数とみなせる。

生成された二次電子は, 固体内部で，フォノン，プラズ モン（金属の場合），あるいは不純物や欠陥などの散乱中心 により散乱される。固体の外部に脱出できる二次電子の数 は，原理的にはこうした散乱過程を組み入れて計算される が，電子の実効的な平均自由行程 $\lambda$ を用いることにより，

$$
g(z)=B \exp \left(-\frac{z}{\lambda}\right)
$$

と表すことが可能である。ここで， $B$ は表面での脱出確率 であり, 仕事関数や表面の污れ，あるいは帯電など材料の 表面状態に依存した量である。

二次電子放出係数 (SEY : secondary electron yield, 1 個の 一次粒子が入射した時に放出される二次電子の個数） $\delta$ は, したがって, (1), ( 3 )式から,

$$
\delta=\int_{0}^{R} n(z) g(z) d z=B \int_{0}^{R}-\frac{1}{\beta} \frac{d E(z)}{d z} \exp \left(-\frac{z}{\lambda}\right) d z
$$

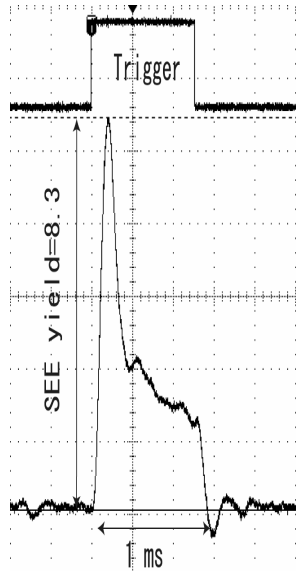

図 1 二次電子放出係数の測定例

Fig. 1. An example of secondary electron yield measurement (primary electron beam current is $100 \mathrm{pA}$ ).

と表すことができる。 $R$ は一次粒子の投影飛程であり, 入 射エネルギーの増加とともに増加する。(4)式は準経験的に 得られたものであり, 各種材料について二次電子放出特性 を説明する際に用いられている。一次粒子の入射エネルギ 一が低く $R$ が $\lambda$ と同程度か小さい場合, 生成された二次電 子はほとんどが放出される。したがって生成個数が入射工 ネルギーに比例すると考えれば， $\delta$ も入射エネルギーにほぼ 比例して増加する。これに対して, 入射エネルギーが高い 場合は深さ $\lambda$ より浅い場所で生成された二次電子だけが脱 出でき, $\delta$ は(2)式からおよそ $1 / E^{\alpha}$ で減少する。

金属と絶縁物とで $\delta$ の值が大きく異なる最大の理由は, (4)式における平均自由行程 $\lambda$ の違いである。金属では自由 電子によるプラズモンの散乱の影響が大きく, $\lambda$ は 0.4 から $1 \mathrm{~nm}$ と小さい。これに対して絶縁物では入は 50 から $100 \mathrm{~nm}$ となり, このため $g(z)$ の值そのものが大きく $\delta$ も数倍の大き さとなる。絶縁体材料においては, $\lambda$ を支配する要因はフォ ノン散乱 (材料温度) および散乱中心となる材料の表面付 近における微細構造であり, 例えばアルミナセラミックス では粒界焼結助剤の結晶性や研磨による欠陥などが強く影 響を及ぼす。

〈2·2〉帯電現象絶縁体に特有なもう一つの現象で ある帯電は, 電子の付着 (束縛, トラップ) あるいは電子 の欠落により表面近傍に局所的な高電界が発生する現象で ある。これが誘因となる絶縁破壊過程は, 一般には, なだ れ的なもの（付着電荷が帯電電界により加速され結晶格子 を破壊する）と, 熱的なもの（外部電界中での電荷の運動 による抵抗損失発熱が原因の材料劣化）とがあると言われ ている。帯電が存在する場合は局所的に静電エネルギーが 材料中に存在することになるが，これは微視的には結晶格 子の歪みによる力学的エネルギーとして蓄えられ放電の際 に放出される。なお, 材料表面での絶縁破壊が起きる帯電 電荷密度は, 経験的に, 数十 $\mu \mathrm{C} / \mathrm{m}^{2}$ 程度と言われているが, これは表面の原子密度のおよそ $1 / 10000$ から同程度に相当 する。絶縁耐力の高い絶縁体材料を開発するためには, 電 
子の束縛準位を調べることが重要であり, さらに，帯電分 布（深さ方向も含めた）の時間的変化を分析することが必 要となる。

絶縁体材料における電子の束縛位置やエネルギー（束縛 準位）については，未だ明確になっていない点が多い。結 晶の格子欠陥や結晶粒界, さらに不純物などが想定されて いる。アルミナセラミックスでは, 表面研磨や熱処理など により，アルミナ結晶の酸素欠陥での電子準位間の遷移と 同時に表面の帯電状態も変化する。このことから, 酸素欠 陥が帯電に直接関連していると推察されている ${ }^{(4)}$ 。

一次粒子を照射した際の帯電の時間変化については，例 えば，二次電子の放出の様子を観察することでも可能であ る。図 1 は, パルス状電子ビームをアルミナセラミックス に入射した際に観察される放出二次電子（電流）であるが, 入射直後から帯電の影響により二次電子放出電流が減少し ていく事が分かる。これは, 電子を放出することよって表 面が正に帯電し, 入射電子の入射エネルギーが相対的に増 加したためである。電子を照射した場合，先に述べたよう に固体内部での飛程まで一次電子は侵入し二次電子を生成 しているので, それらが放出されない入より深い領域では, 一次と二次を含めた電子の密度は分布を持つ（均一ではな く広義には帯電)。深さ方向の電荷分布は熱刺激パルス法等 で測定されることがあるが, 数千 $\mathrm{nm}$ (飛程) の表面近傍で の精度や位置分解能を得ることは難しい。現在のところは, 散逸過程と散乱過程とを仮定したシミュレーションによる 電荷分布の推定が行われている(5)。

\section{3. 高電圧真空遮断器開発の技術的課題}

〈3.1〉技術的背景と課題 真空遮断器 (VCB) は構 造が単純で環境調和，メンテナンスフリーなどのメリット があるため, $84 \mathrm{kV}$ 級までの汎用遮断器として電力システ ム・配電システムに多用されている。最近では $\mathrm{SF}_{6}$ ガスの地 球温暖化問題から, 将来の電力送変電用遮断器として高電 圧化の技術開発が開始されている。真空バルブ $(\mathrm{VI})$ が $84 \mathrm{kV}$ 級以上の高電圧条件で使用されるためには, 高電圧電気絶 縁技術の開発はもとより, 真空バルブの通電電流性能向上, 冷却性能向上, 短絡容量向上などを達成し，単一バルブの 大幅なコンパクト化を実現する技術開発が求められる ${ }^{(6)(7)}$ 。 以下では, 真空バルブの $110 \mathrm{kV} \sim 168 \mathrm{kV}$ 級への高電圧化に 関する電気絶縁技術の課題についてまとめる。

〈3·2〉 真空バルブの電気絶縁設計技術 真空バルブ （VI）の電気絶縁設計に関する部位とそれに関する電気絶 縁部位を分類すると図 2 のようになる。この中で VIを高電 圧化する上で特に重要となるのが，メインコンタクト間, アルミナセラミックスの沿面電気絶縁など( 1$)$ ( 4 )で示し た部分である。高電圧化するためには準平等電界分布にお ける絶縁特性に加えて不平等電界分布における絶縁特性一 の配慮が重要になってくる。

メインコンタクトやシールド閒などの電極間では電極材 料特性の改良のほか, フラッシオーバ特性の電極面積効果,

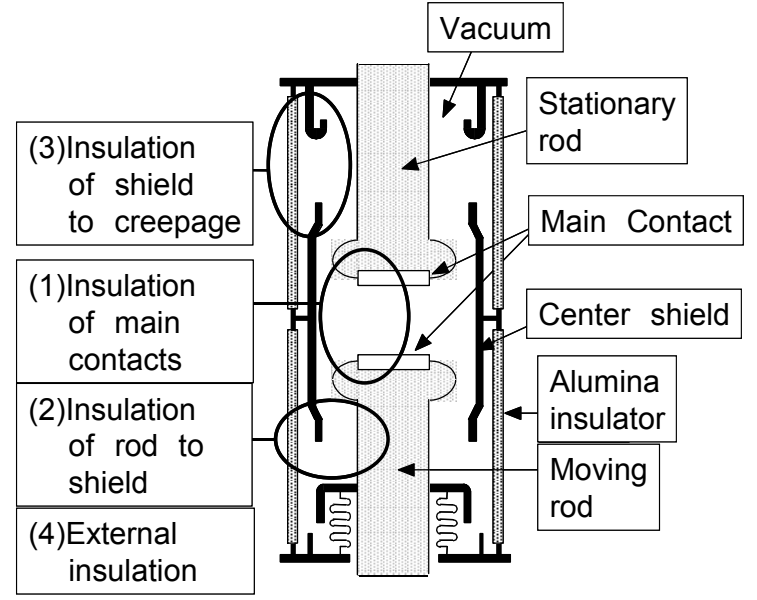

図 2 真空バルブ(VI)の電気絶縁部位の分類

Fig. 2. Classification of electrical insulation part of vacuum interrupter.

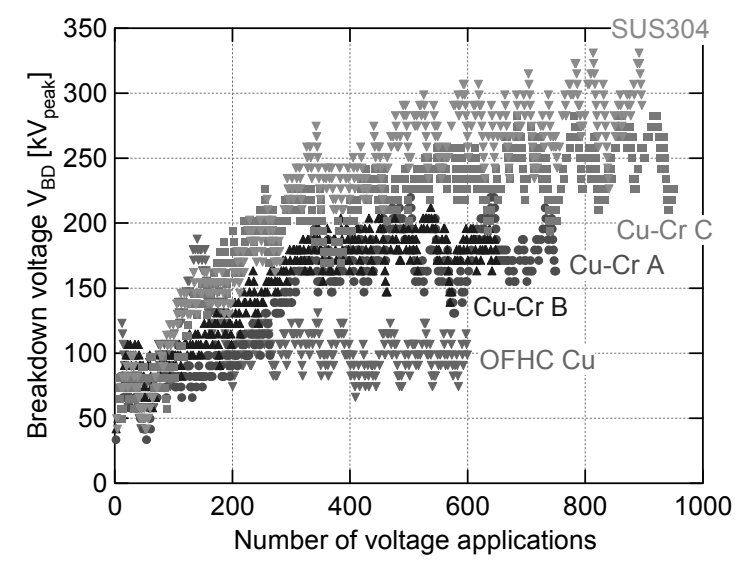

(a) Electrode material characteristics

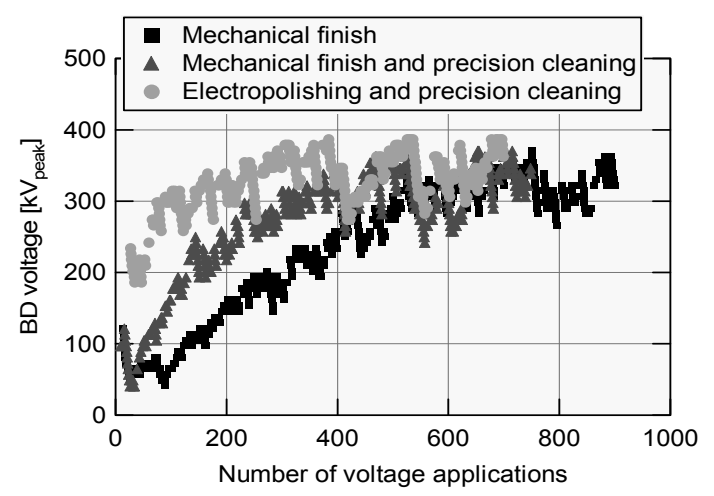

(b) Electrode pre-treatment effect

図 3 絶縁破壊電圧のコンディショニング効果

Fig. 3. Conditioning effect of breakdown voltage.

電極コンディショニング特性の把握などが必要であり, 沿 面絶縁についてはアルミナセラミックスの帯電特性や沿面 フラッシオーバ特性の体系化が求められている( ${ }^{(6)}$ 。最近で は, 電荷重畳法 (CSM) を応用した電界最適化法や電気絶 縁最適化法を用いて, 目標とする電界分布や目標耐電圧条 件を満たす電極形状の逆求解手法が適用されている ${ }^{(8)}$ 。 


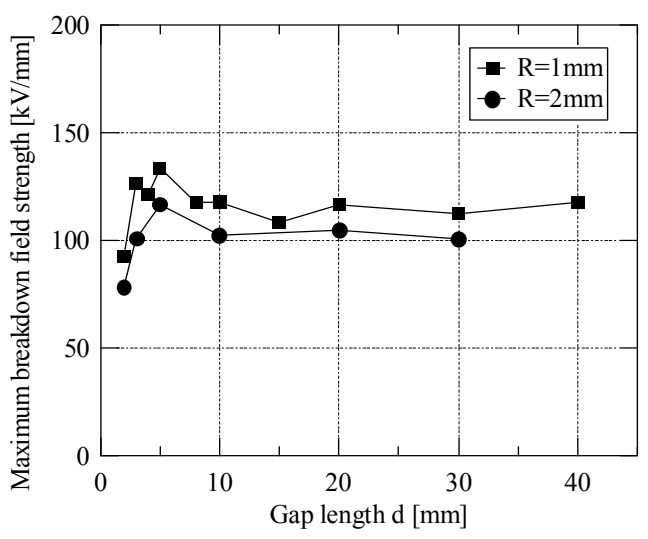

図 4 真空中長ギャップ絶縁破壊電界特性

Fig. 4. Breakdown field characteristics of long gap electrodes.

このように，電極材料開発，電極コンディショニング特 性の定量化, 沿面帯電の低減施策, それに各種最適化手法 を駆使して，長ギャップ不平等電界特性の把握や従来の限 界を打破し，VI の高電圧化電気絶縁技術開発が行われてい る。145 kV，2000 A， $40 \mathrm{kA}$ 級 VCB / VI の開発結果が報告 されている(9)

〈3·3〉 不平等·長ギャップ電極コンディショニング特 性従来より真空中の電極ギャップは電圧の印加や電界 の印加, 電流通電などにより絶縁破壊電圧を上昇させる ${ }^{(10)}$ 。 このコンディショニング特性を定量化し効率よく適用する ことが VI の高電圧化に繋がる。図 3 に代表的な電極コンデ イショニング特性の例を示す(11)(12)。同図(a)から材料による 違いが明らかであり，また同図(b)から電極表面処理すなお ち, 電界研磨と超純水による表面洗浄が耐電圧向上に効果 的であることがわかる(13)。

図 4 には不平等電界電極による $40 \mathrm{~mm}$ までの長ギャップ 絶縁破壊特性を示す。 $10 \mathrm{~mm}$ 以上の長ギャップ条件下では 最大破壊電界はほぼ一定となっている(14)。このように，電 極材料とその処理, 表面粗さなどによるコンディショニン グ特性が不平等電界下で定量化され，不平等電界下におけ る面積効果の体系化が進められている。このほかに，VIの 高電圧化に対して，メインコンタクトの複数ギャップ化に よる効率向上の研究などがおこなわれている ${ }^{(15)}$ 。

$\langle 3 \cdot 4\rangle$ 真空中固体絶縁物の帯電と沿面フラッシオーバ 特性真空中固体絶縁物表面の電気絶縁，すなわち沿面 絶縁特性が VI 高電圧化のための重要技術となっている。シ ールド電極やトリプルジャンクションからの電界電子放出 により固体絶縁物表面が带電し沿面放電発生に至る可能性 が指摘されている。図 5 に PMMA 製の円筒および円柱型試 料の表面粗さに対する帯電特性を精密に測定した事例を示 す(16)。また図 6 には, アルミナセラミックス表面粗さと電 界分布を同時に変化させ，電気力線のセラミックス表面入 射角度を制御し，表面の帯電特性の違いを定量化している。 これらの知見により, 図 7 に示すようにアルミナセラミッ クス表面粗さと電界分布を変化させることにより，アルミ

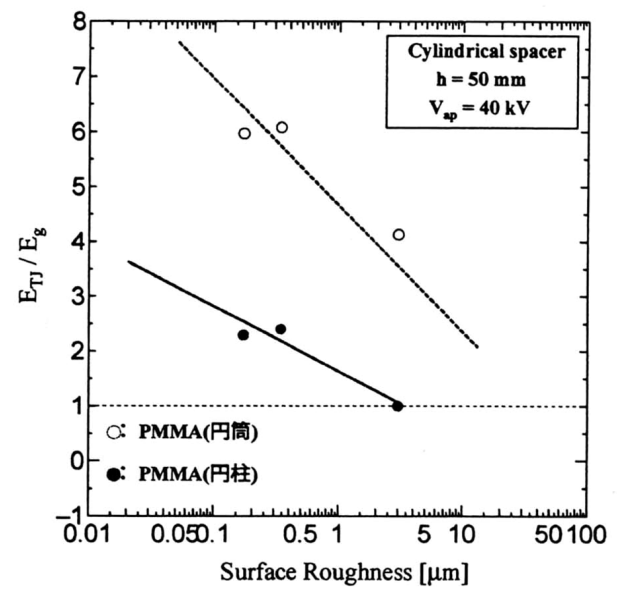

図 5 PMMA 表面粗さと帯電強度の関係

Fig. 5. Relationship between PMMA surface roughness and charging intensity.

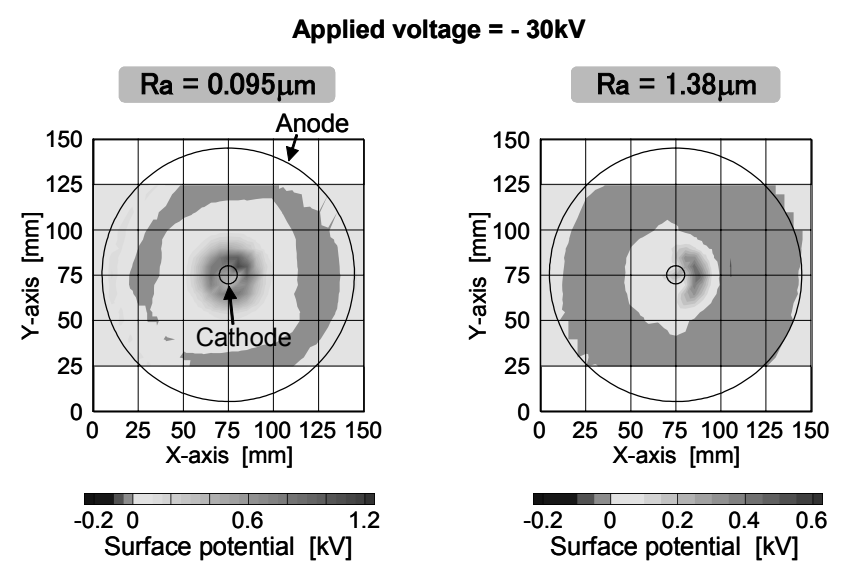

図 6 真空中帯電の二次電子放出とアルミナセラミック 表面粗さの影響

Fig. 6. Influence of secondary electron emission and surface roughness on surface charging in vacuum.

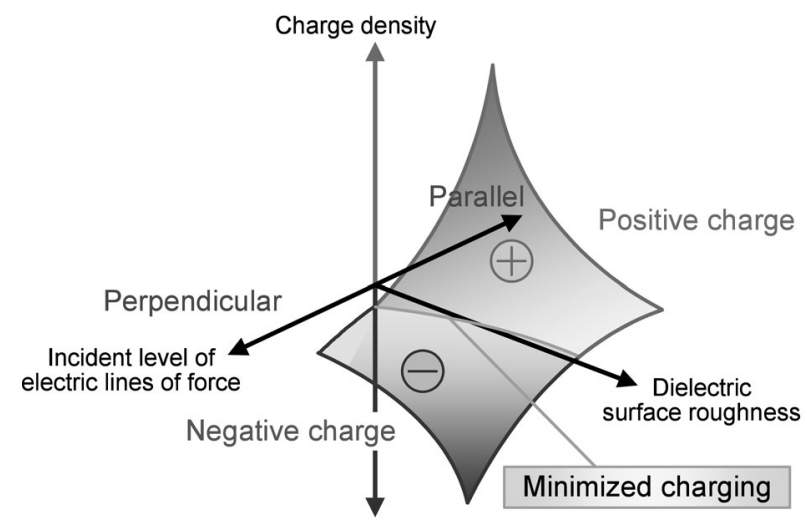

図 7 真空中アルミナセラミックス帯電の制御特性

Fig. 7. Charging control of ceramics charging in vacuum. 
ナセラミックス表面の帯電特性を制御できることが明らか になっている(17)。さらに，低電圧 VI ではあるが，中間シー ルドを除去した VI の開発の試みもなされている ${ }^{(18)}$ 。

\section{4. 簡易型核融合中性子／陽子源の開発における 諸問題}

ITER（国際熱核融合実験炉）に代表されるように，核融 合というとエネルギー源としての応用を目指した非常に大 がかりな装置が一般的である。しかしながら，核融合反応 を得ること自体はそれほど難しいものではなく，例えば重 水素を含む気体中で高電圧の放電を起こすだけで簡単に核 融合は起きてしまう。そこで, 図 8 に示す装置を使って, 核融合をエネルギー源としてではなく簡便な中性子源ある いは陽子源として利用寸る研究が進められている ${ }^{(19)}$ 。この 装置は，陽極となる球形もしくは円筒形の真空容器内に同 心・同形のグリッド陰極を設置しただけの非常に簡単な構 造で, 大きさも直径 $20 \mathrm{~cm}$ 程度から実現可能である。陰極 に開口率の高いグリッドが使われていることが大きな特徴 で, 電極間に数十 $\mathrm{kV}$ の高電圧を印加して放電すると, 放電 によって生成されたイオンが電界によって中心に向かって 加速され, 収束したイオンビーム同士が衝突して核融合反 応が起こる。この電極構造では，イオンが衝突することな く陰極の反対側に通り抜けたとしても, 逆方向の電界によ って再度中心に向かって加速されるため, 衝突が起こるま でイオンは装置内を運動し続け, 効率よく核融合反応が得 られる。

$\langle 4 \cdot 1\rangle$ 原理的課題ここの核融合装置の構造や動作原 理は簡単であるが，中性子／陽子生成率を大きくすること は容易ではない。その主な原因の 1 つが，加速されたイオ ンビームの多くが核融合反応を起こす前に荷電交換反応で 中性粒子化してしまうことにある。一旦中性粒子化してし まうと, 他の粒子と衝突が起こらなかった場合はそのまま 真空容器壁に衝突し, 損失となるため, 装置本来の構造に よる利点が活かされない。これは, バックグラウンドの圧 力の高さに起因しているが, 放電との依存関係があるため,

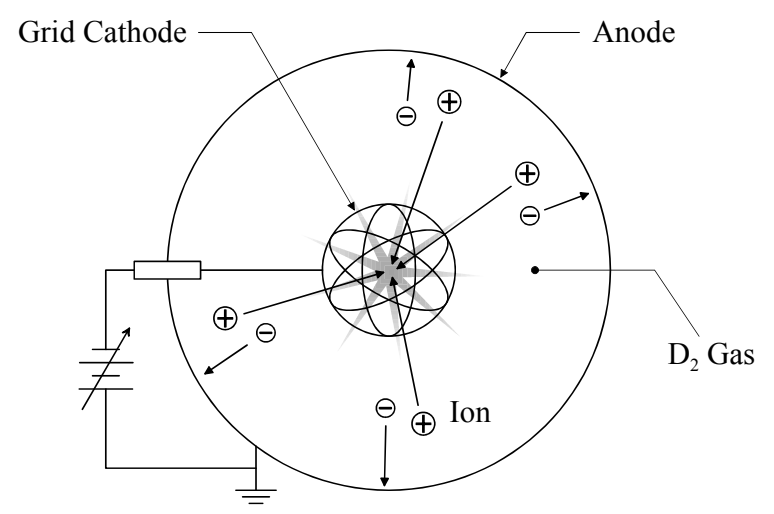

図 8 簡易型核融合中性子/陽子源の装置概略

Fig. 8. Schematic of discharge-type fusion neutron/proton source.
圧力だけを単純に下げることはできない。また, 本来の動 作原理からすると放電電流の 2 乗に比例するビームービー ム衝突反応が支配的となってよいはずであるが，実際には 図 9 に示されるように放電電流の 1 乗に比例するビームー バックグラウンド衝突反応が支配的となっているのも, 同 様にバックグラウンド圧力の高さに起因している。そのた め, さまざまなイオン源を用いて動作圧力を下げる試みが なされているが，イオン源自体の動作もまた圧力に依存す るため, 中性子／陽子生成率が向上するかわりに動作安定 性が悪くなるなど, 著しい効果を得るまでには至っていな い(20) (22)

こうした中性子／陽子生成率の課題は依然として残され てはいるものの，一方では非常に簡便な中性子／陽子源が 得られるということで, 以下の具体的応用を見据えた研究 もなされている。

$\langle 4 \cdot 2\rangle$ 地雷探知用可搬型中性子源の開発 現在, こ の核融合装置を地雷探知用の可搬型中性子源として応用寸 る研究が進められている(23)。火薬中の窒素に中性子があた ると, 特定のエネルギーを持った捕獲ガンマ線が放出され る性質を利用するもので, 金属探知器に反応しないプラス チック製の対人地雷も探知できる。

対象が危険物であることから探知精度の高さが第 1 に優 先されるが，その上で実用的な時間内に探知が行われるた めには, 毎秒 $10^{7}$ 個以上の高い中性子生成率が必要となる。 しかしながら, そのためには高電圧・大電流での運転が必 要であり, 可搬性の高い小型の装置でそのような高出力を 実現するためには, 装置の過熱を防ぐために十分な冷却が 不可欠となる。

なお，この技術は現在のところもつぱら地雷探知に主眼 が置かれて研究開発が行われているが，空港等でのセキュ リティチェックにもほぼそのまま適用できるため, 多方面 から高い期待が寄せられている。

$\langle 4 \cdot 3\rangle$ 短寿命放射性同位体生成用陽子源の開発近 年, 国民病とまで言われるがんの先進的な検診法として陽

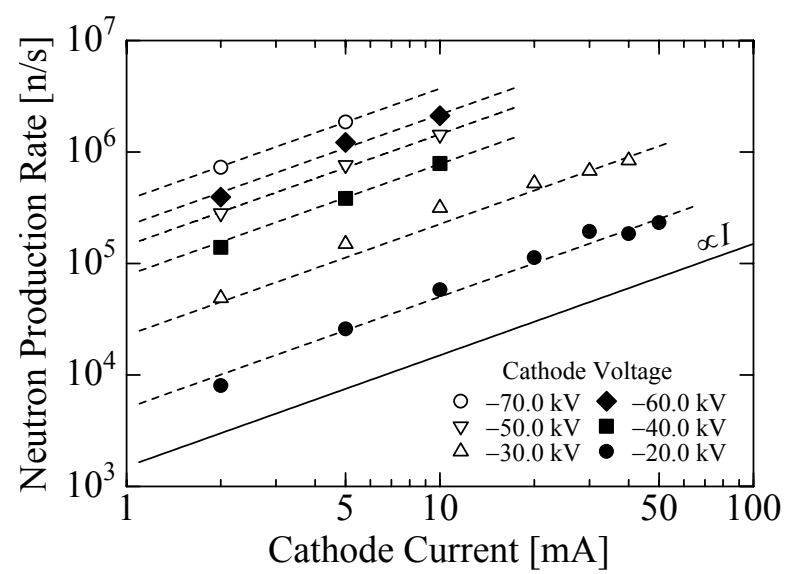

図 9 中性子生成率と陰極電流の関係

Fig. 9. Neutron production rate vs. cathode current at constant voltages. 
電子放射断層撮影（PET）診断が注目されている。PET 診断 では，陽電子放出を行う放射性同位体を製剤として体内に 注入する必要があるが，同位体生成には高エネルギーの陽 子が必要なだけでなく, 短寿命であるが故に検査現場近く での生成が不可欠である。現在のところ，この同位体生成 には高価なサイクロトロン加速器が用いられているが, 設 置スペースや初期コストの問題で普及が遅れている。そこ で，この放電型核融合装置をサイクロトロンにかわる安価 で小型の陽子源として応用する研究が進められている。

PET 診断に用いられる同位体は短寿命であるため, その 生成には非常に高い陽子線量が要求される。そのため, 絶 対的な陽子生成量を稼ぐことが最も大きな課題ではある が, 透過力の非常に高い中性子と異なり陽子は引き出せる 量がかなり制限されるため, いかにして生成した陽子を標 的に多く照射できるようにするかが重要な課題となる。ま た，D-D 反応では生成される陽子のエネルギーが十分では ないため, より高エネルギーの陽子を生成する $\mathrm{D}-{ }^{3} \mathrm{He}$ 反応 が同位体生成には有効であるが, ヘリウム 3 が高価で調達 が難しいという問題もある。

\section{5. 放電電流の制御による軟 $X$ 線源の開発}

真空アーク放電では, 放電開始直後より電極から高密度 のプラズマが発生する。導電性のプラズマは回路電流の経 路となるので, プラズマの進展と回路の応答とは密接に影 響し合っている。このため, 真空アークの応用ではアーク プラズマの過渡現象に応じた回路電流の制御が必要になる 場合がある。ここでは, 真空アークを利用した高輝度軟 X 線源を実現するために, 二つの共振回路を用いて二周波数 成分からなるアーク電流を発生させる試みを紹介する。

近年, 低原子番号の原子との相互作用を起こし易い $1 \mathrm{keV}$ 領域の軟 X線が注目されている。真空放電を利用した高強 度のX線源として, 真空スパーク X線源がよく知られてい $ろ^{(24)}$ 。一般にX 線発生の効率を高めるために高い印加電圧 を用いると, 利用したい軟X線以外に高エネルギーのX線 が混入する。軟X線のみを高輝度で発生させるためには, 低い加速電圧で大電流密度の電子流を発生させる必要があ る。

この目的のために開発した繰り返し真空アーク軟X線源 を図 10 に示す。この装置は真空ギャップにおいて短時間の アーク放電と高電圧の印加を交互に繰り返すことにより, アーク消弧後の高温の陰極表面から熱電子を発生させ，同 時にイオンシース中で加速し，陽極で制動放射を得るもの である(25)(26)。真空ギャップと電源との間に二つの共振器 (同 軸キャパシタ）および抵抗を接続することで，ギャップの ブレークダウン時に高周波と低周波が重畳したアーク放電 電流を励振させ，これを弛緩発振により繰り返す。

図 11(a)にブレークダウン時の電極間電圧および電流波形 を示す。抵抗と二つの同軸キャパシタの静電容量によって 決定される時定数で回路が充電されてゆき, $10 \mathrm{kV}$ 程度に達 した時に真空ギャップのブレークダウンが起こる。すると

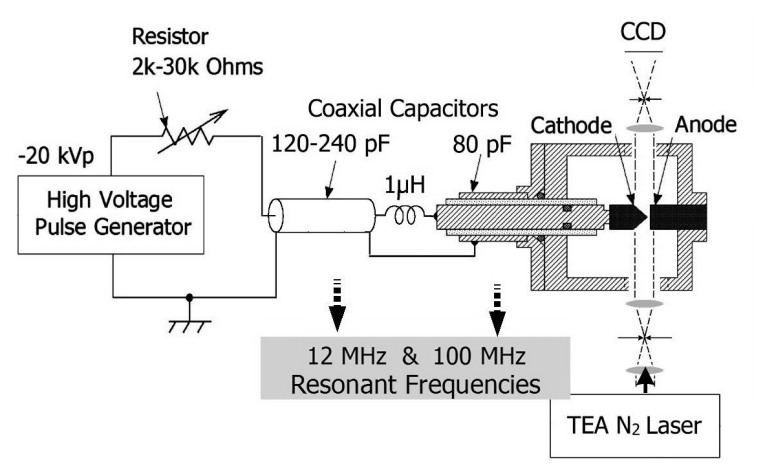

図 10 繰り返し真空アーク軟X線源の構成

Fig. 10. Repetitive vacuum arc soft X-ray source.

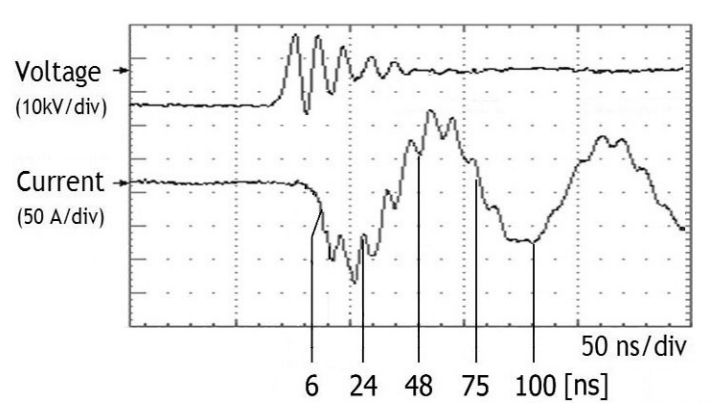

(a) Voltage and current measured at the connection of two resonators (High frequency component of the current is attenuated by 0.03 )

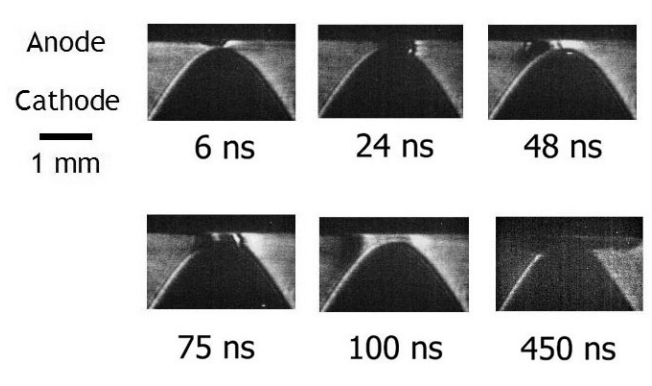

(b) Photographs of the plasma

図 11 高周波および低周波電流によるアークプラズマの 生成と進展

Fig. 11. Time evolution of plasma generated with high and low frequency currents.

放電初期に高周波電流をともなうプラズマが発生する。プ ラズマの時間進展をシュリーレン法により撮影したのが同 図(b)で, 初期プラズマが電極間を接続していることがわか る（6４8 ns）。この時間帯では半径方向の電子密度勾配を 示す黒い部分（左）と白い部分（右）とが区別できる。こ の時間帯では, プラズマの直径は $1 \mathrm{~mm}$ 以下である。その後, 低周波成分の電流の反転によって, 第二のプラズマ層が生 成されるが, 新しいプラズマの膨張は外側のプラズマ層に よって妨げられている。75 ns では直径 $1.5 \mathrm{~mm}$ のプラズマの 中に直径 $0.4 \mathrm{~mm}$ のプラズマ層が見られる。次第にプラズマ 柱の膨張および拡散が起こり, $100 \mathrm{~ns}$ では電流が継続してい るものの, 新しいプラズマの発生は認められない。両電極 


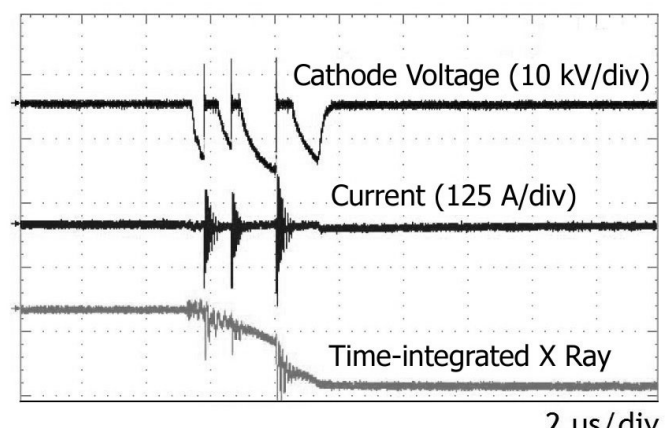

$2 \mu \mathrm{s} / \mathrm{div}$

軟X線の出力はシンチレータと光電子増倍管の組み合わせ により時間積分している

図 12 繰り返し動作時の電極間電圧，電流 および軟 X線放射

Fig. 12. Waveforms of electrode voltage, current, and timeintegrated intensity of soft X-ray emission.

の表面は広い範囲でプラズマと接触しているため電流密度 は低下し，新たな陰極点が発生しにくいためと考えられる。 $450 \mathrm{~ns}$ では, 低周波電流により加熱された電極からの蒸気が 陽極表面に広がり停滞していると考えられる。

このように, 各共振器に蓄積されたエネルギーが異なる 時間的割合で真空ギャップへ伝達され，それぞれの作用に より高密度プラズマが生成され, 電極が加熱されているこ とがわかる。ギャップ間を電気的に接続していたプラズマ が消滅すると同軸キャパシタは再び充電され, 以上のプロ セスが約 $1 \mu \mathrm{s}$ の時間間隔で繰り返される（図 12）。

アーク消弧後に負電圧が陰極に印加される期間には陰極 の周辺にイオンシースが形成される。このとき，陰極の温 度が低下寸る前に軟 $\mathrm{X}$ 線放射に必要な電圧が印加されるよ うに回路定数を選択すれば，陰極から発生した熱電子をイ オンシース中で加速し，陽極への衝突によって制動放射を 得ることが出来る。実験の結果, X 線放射の起こる点状領 域のプラズマの直径は $170 \mu \mathrm{m}$ 程度であり, 電流密度は, $10^{7}$ $\mathrm{A} / \mathrm{m}^{2}$ であった。これはマイクロフォーカス X 線源の電流密 度に匹敵あるいは上回る值である。本方式では高真空を必 要とせず, ウォーミングアップも不要であるため, 電池を 電源とした可搬式の分析機器への応用が考えられる。

\section{6. おわりに}

真空環境を利用する機器には電力機器, 電子機器, 高エ ネルギー物理学関連機器, 医療・医学関連機器さらに宇宙 関連機器などがあり，それぞれの立場から放電を制御ない し利用するための研究も多様である。この解説記事でその 一端を理解して頂ければ幸いである。最後に，本年（2006 年）9月には当調査専門委員会が中核となって企画した第 22 回真空中の放電と絶縁に関する国際会議 (XXII ${ }^{\text {nd }}$ International Symposium on Discharges and Electrical Insulation in Vacuum）が松江にて開催されることを記して本稿を終え る。

(平成 18 年 5 月 30 日受付)

\section{文献}

(1)「真空中での放電の利用とその制御」，電気学会技術報告， No.586 (1996)

（2）「真空中での荷電粒子の発生と放電の制御」，電気学会技術報告, No.757 (1999)

(3)「高エネルギー密度化に係わる真空中の放電制御技術」, 電気学会技 術報告, No.1001 (2005)

(4) S. Michizono, Y. Saito, and A. Inagaki : "Annealing Effects on Breakdown Threshold of Radio-frequency Windows”, J. Vac. Soc. Jpn., Vol.40, pp.436-441 (1997)

(5) C. Attard, G. Damamme, J-P. Ganachaud, R. Renoud, and E. Vicario : "Monte Carlo simulation of the building up of a charge distribution in an insulating target and of its relaxation in an electrostatic mirror experiment", Proc. $3^{\text {rd }}$ International Conf. Electrical Charge in Solid Insulators, pp. 215-223, Tours, France (1998-7)

(6) H. Okubo : "Technical Trend of Environmental-friendly High Voltage Vacuum Circuit Breaker (VCB)", IEEJ Trans. FM, Vol.123-B, No.2, pp.129-132 (2003-2) (in Japanese) 大久保仁:「解説一環境低負荷の真空遮断器 $(\mathrm{VCB})$ 高電圧化技術動 向」, 電学論 B, 123, 2, pp.129-132 (2003-2)

( 7 ) H. Okubo and S. Yanabu : "Feasibility Study on Application of High Voltage and High Power Vacuum Circuit Breaker", 20th International Symposium on Discharges and Electrical Insulation in Vacuum (ISDEIV), pp.275-278 (2002)

( 8 ) K. Kato, S. Okabe, S. Kaneko, and H. Okubo : "Optimization Technique Taking Area Effect into Account for Computer-aided Insulation Design of Vacuum Circuit Breakers", 21th International Symposium on Discharges and Electrical Insulation in Vacuum (ISDEIV), pp.610-613 (2004)

(9) H. Saitoh, H. Ichikawa, A. Nishijima, Y. Matsui, M. Sakaki, A. Honma, and H.Okubo : "Research and Development on $145 \mathrm{kV} / 40 \mathrm{kA}$ One Break Vacuum Circuit Breaker", IEEE PES Transmission and Distribution Conference and Exhibition 2002: Asia Pacific, Vol.2, pp.1465-1468 (2002)

(10) Y. Ito, Y. Yamano, S. Kobayashi, and Y. Saito : "Vacuum Electrical Breakdown Characteristics and Surface Chemical Compositions of Titanium Electorodes with Oxidation Conditions", 21th International Symposium on Discharges and Electrical Insulation in Vacuum (ISDEIV), pp. $80-83$ (2004)

(11) F. Miyazaki, Y. Inagawa, K. Kato, M. Sakaki, H. Ichikawa, and H. Okubo : "Electrode Conditioning Characteristics in Vacuum under Impulse Voltage Application in Non-uniform Electric Field", IEEE Trans. Dielect. Elect. Insulation, Vol.12, pp.17-23, No.1 (2005)

(12) H. Okubo, F. Miyazaki, Y. Inagawa, K. Kato, M. Sakaki, and H. Ichikawa : "Electrode Area of Breakdown Depending on Conditioning Mechanism under Non-uniform Electric Field in Vacuum", 21th International Symposium on Discharges and Electrical Insulation in Vacuum (ISDEIV), pp.76-79 (2004)

(13) K. Kato, Y. Fukuoka, Y. Inagawa, H. Saitoh, M. Sakaki, and H. Okubo : "Breakdown Conditioning Characteristics of Presicion- surface-treatment", IEEJ Trans. FM, Vol.126, No.8, pp.763-768 (2006-8) (in Japanese) 加藤克巳 福岡裕志 $\cdot$ 稲川諭季彦・斉藤 仁 $\cdot$ 榊 正幸 $\cdot$ 大久保仁 : 「真空中精密表面処理電極のコンディショニング特性」, 電学論 $\mathrm{A}$, 126, 8, pp.763-768 (2006-8)

(14) Y. Fukuoka, K. Kato, H. Saitoh, M. Sakaki, and H. Okubo : "Conditioning Characteristics of Large Gap Electrode under Non-uniform Electric Field in Vacuum", The Papers of Technical Meeting on Electrical Discharges, IEE Japan, ED-05-162 (2005) (in Japanese)

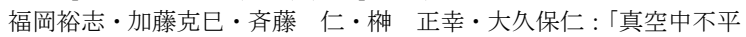
等電界下長ギャップ領域における電極コンディショニング特性」, 電 気学会放電研資, ED-05-162 (2005)

(15) S. Giere, H. C. Karner, and H. Knobloch : "Dielectric Strength of Double and Single-Break Vacuum Interrupters", IEEE Trans. Dielect. Elect. Insulation, Vol.8, No.1, pp.43-47 (2001)

(16) Y. Hayashi, T. Satoh, S. Hamada, O. Yamamoto, T. Kobayashi, H. Omura, and H. Morii : "Charging Characteristics of a Hollow Insulator in Vacuum”, 2006 National Convention Record, IEE of Japan, No.1, p.46 (2006) (in Japanese) 林 泰隆・佐藤剛洋・濱田昌司 $\cdot$ 山本 修 ・ 小林哲夫 ・ 小村広司 . 森井 浩: 「真空中円筒型固体絶縁物の帯電特性」, 平成 18 年電気学 
会全国大会, No.1, p.46 (2006)

(17) T. Hosono, K. Kato, A. Morita, and H. Okubo : "Experimental Investigation on the Charging Control for Electric Filed Distribution on Alumina Insulator in Vacuum", The Papers of Technical Meeting on Electrical Discharges, IEE Japan, ED-05-144 (2005) (in Japanese) 細野喬文・加藤克巳・森田 歩・大久保仁：「電界分布と表面粗さに よる真空中アルミナ絶縁物上帯電制御に関する実験的検討」, 電気学 会放電研資，ED-05-144 (2005)

(18) L. T. Falkingham : "Fifty years of Vacuum Interrupter Development in the UK", $20^{\text {th }}$ International Symposium on Discharges and Electrical Insulation in Vacuum (ISDEIV), pp.1-8 (2002)

(19) G. H. Miley, J. Javedani, Y. Yamamoto, R. Nebel, J. Nadler, Y. Gu, A. Satsangi, and P. Heck : "Inertial-Electrostatic Confinement Neutron/Proton Source", Proc. of 3rd Int. Conf. on Dense Z-pinches, pp.675-688, AIP Press, New York (1994)

(20) K. Masuda, K. Taruya, T. Koyama, H. Hashimoto, K. Yoshikawa, H. Toku, Y. Yamamoto, M. Ohnishi, H. Horiike, and N. Inoue : "Performance Characteristics of an Inertial Electrostatic Confinement Fusion Device with a Triple-Grid System", Fusion Technol., Vol.39, No.3, pp.1202-1210 (2001)

(21) T. Takamatsu, K. Masuda, T. Kyunai, H. Toku, and K. Yoshikawa : "Inertial Electrostatic Confinement Fusion Device with an Ion Source Using a Magnetron Discharge", Nucl. Fusion, Vol.46, No.1, pp.142-148 (2006)

(22) K. Yamauchi, S. Ohura, A. Tashiro, M. Watanabe, A. Okino, T. Kohno, E. Hotta, and M. Yuura : "Improvement of Proton Source based on Cylindrical Inertial Electrostatic Confinement Fusion with Ion Source", Workshop on New Aspects of High Energy Density Plasma, NIFS-PROC-61, pp.99-104 (2005)

(23) K. Yoshikawa, K. Masuda, H. Toku, K. Nagasaki, T. Mizutani, T. Takamatsu, M. Imoto, Y. Yamamoto, M. Ohnishi, H. Osawa, E. Hotta, T. Kohno, A. Okino, M. Watanabe, K. Yamauchi, M. Yuura, S. Shiroya, T. Misawa, and T. Mori : "Research and Development of Landmine Detection System by a Compact Fusion Neutron Source", Fusion Sci. Technol., Vol.47, No.4, pp.1224-1228 (2005)

(24) R. Germer : "X-ray flash techniques", J. Phys. E: Sci. Instrum., Vol.12, pp.336-350 (1979)

(25) T. Yanagidaira, D. Nose, H. Abiko, H. Miura, and K. Tsuruta : "Soft X-ray Generation after Arc Extinction of a Short Vacuum Gap Operated with Low-Current, Repetitive Discharge", Plasma Sources Sci. Technol., Vol.13, pp.116-120 (2004)

(26) T. Yanagidaira, W. Kotake, H. Miura, and K. Tsuruta : "Temporal Evolution of Micro-Plasma in a Low-Current, Repetitive Vacuum Spark Soft X-Ray Source", IEEE Trans. Plasma Sci., Vol. 33, No. 5, pp.1668-1671 (2005)

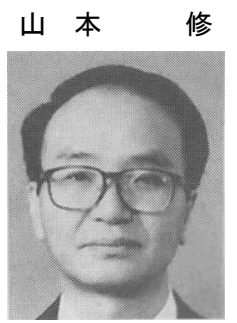

（正員） 1948 年 2 月 22 日生。 1970 年 3 月立 命館大学理工学部数学物理学科卒業。京都大学 工学研究科助手。工学博士。 $\mathrm{SF}_{6}$ ガスおよび混 合ガス絶縁，鉄塔雷サージ特性，混合ガスの分 離回収法，真空中の沿面絶縁などの研究に従 事。IEEE 会員，放電学会会員。

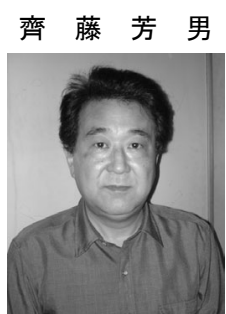

（正員） 1951 年 6 月 10 日生。1979 年 3 月東 京大学大学院工学系研究科物理工学専攻博士 課程修了。同年同大学工学部計数工学科助手。 1980 年高エネルギー物理学研究所助手。2003 年高エネルギー加速器研究機構教授。加速器の 真空システムの開発研究に従事。工学博士。 IEEE, AVS, 日本真空協会, 応用物理学会会員。

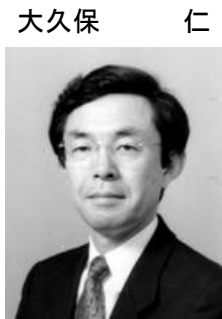

（正員） 1948 年 10 月 29 日生。1973 年 3 月名 古屋大学大学院工学研究科博士課程前期課程 修了。同年 4 月東芝入社。高電圧技術開発に従 事。1976 年 7 月〜1978 年 2 月ドイツ・アーヘ ン工科大学高電圧研究所およびミュンヘン工 科大学高電圧研究所客員研究員。1989 年 7 月名 古屋大学工学部電気学科助教授, 1991 年 4 月同 教授, 2004 年 4 月名古屋大学エコトピア科学研 究所教授, 現在に至る。工学博士。IEEE, VDE, CIGRE 会員。

堀田栄喜

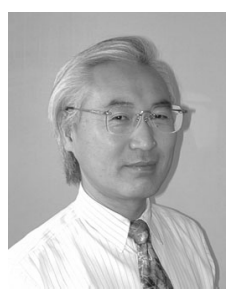

山 内 邦 仁

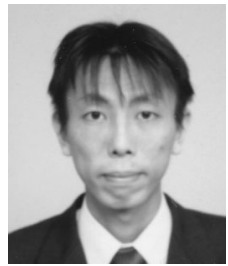

鶴 田 浩 一

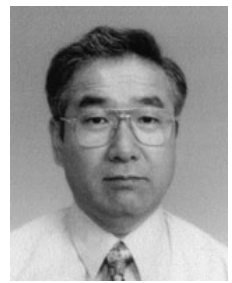

（正員） 1951 年 2 月 8 日生。1978 年 3 月東京 工業大学大学院理工学研究科電気工学専攻博 士課程満期退学, 同年 4 月同大学工学部電気 . 電子工学科助手, 助教授を経て, 1995 年同大学 大学院総合理工学研究科創造エネルギー専攻 教授, 現在に至る。工学博士。現在, パルスパ ワー技術およびプラズマ応用の研究に従事。プ ラズマ・核融合学会, IEEE, 応用物理学会会員。

（正員） 1975 年 10 月 29 日生。2003 年 3 月東 京工業大学大学院総合理工学研究科創造工ネ ルギー専攻修了。同年 4 月より，（独）科学技 術振興機構研究員として超小型放電型中性子 源による地雷探知技術の開発に従事。プラズ マ・核融合学会会員。博士 (工学)。

（正員） 1944 年 6 月生。1967 年 3 月茨城大学 工学部電気工学科卒業。1971 年 4 月同大学工学 部助手。現在, 同電気電子工学科教授。工学博 士。真空及びガス中の絶縁破壊とアーク現象に 関する研究に従事。1987 年 3 月から 1 年間, ブ リティッシコロンビア大学客員研究員, 応用物 理学会会員, 真空協会会員。 